

\title{
Freezing-induced loss of carbon uptake in a subtropical coniferous plantation in southern China
}

Zhang, Wang, Wen, Yang, Ma, Sun, Yu

\section{To cite this version:}

Zhang, Wang, Wen, Yang, Ma, et al.. Freezing-induced loss of carbon uptake in a subtropical coniferous plantation in southern China. Annals of Forest Science, 2011, 68 (6), pp.1151-1161. 10.1007/s13595-011-0120-0 . hal-00930690

\section{HAL Id: hal-00930690 https://hal.science/hal-00930690}

Submitted on 1 Jan 2011

HAL is a multi-disciplinary open access archive for the deposit and dissemination of scientific research documents, whether they are published or not. The documents may come from teaching and research institutions in France or abroad, or from public or private research centers.
L'archive ouverte pluridisciplinaire HAL, est destinée au dépôt et à la diffusion de documents scientifiques de niveau recherche, publiés ou non, émanant des établissements d'enseignement et de recherche français ou étrangers, des laboratoires publics ou privés. 


\title{
Freezing-induced loss of carbon uptake in a subtropical coniferous plantation in southern China
}

\author{
Wenjiang Zhang • Huimin Wang $\cdot$ Xuefa Wen • \\ Fengting Yang $\cdot$ Zeqing Ma $\cdot$ Xiaomin Sun $\cdot$ Guirui Yu
}

Received: 1 November 2010 / Accepted: 7 May 2011 /Published online: 1 September 2011

(C) INRA and Springer Science+Business Media B.V. 2011

\begin{abstract}
- Context In January 2008, a freeze in southern China, unprecedented in 50 years, severely affected local subtropical coniferous plantations.

- Aims We investigated the freezing-induced loss of carbon uptake in a subtropical coniferous plantation at Qianyanzhou site in southern China.

- Methods We used data from eddy covariance observations, field surveys and remote sensing.

- Results Field surveys revealed that the trees (especially slash pine, Pinus elliottii) at forest edges and valley banks were susceptible to the freezing weather, and about $6 \%$ of trees were severely damaged by glaze ice. The vegetation index showed a phenological lag of about 10 days in 2008 due to the freezing weather. Photosynthesis in 2008 was more sensitive to the freezing weather than was ecosystem respiration, and this fact led to significantly less annual carbon uptake. This uptake loss $\left(\sim 66 \mathrm{gC} \mathrm{m}^{-2}, 17 \%\right.$ of annual uptake) was due to the physical damage caused by
\end{abstract}

\section{Handling Editor: Reinhart Ceulemans}

W. Zhang $\cdot$ H. Wang $(\bowtie) \cdot X$. Wen $\cdot$ F. Yang $\cdot$ Z. Ma $\cdot$ X. Sun $\cdot$ G. Yu

Key Laboratory of Ecosystem Network Observation and Modeling, Qianyanzhou Ecological Station,

Institute of Geographic Sciences and Natural Resources Research, Chinese Academy of Sciences,

Beijing 100101, China

e-mail: wanghm@igsnrr.ac.cn

W. Zhang

State Key Laboratory of Hydraulics and Mountain River Engineering, Sichuan University,

Chengdu 610065, China glaze ice and physiological injuries caused by low temperatures. With gradual ecosystem recovery over time, the quarterly ratios of ecosystem respiration to photosynthesis in 2008 returned gradually to normal levels. Because of the seasonal variation of footprint biases with monsoon transition, the flux observations possibly overestimated both carbon uptake loss in early 2008 and ecosystem recovery in the following months to some extent.

Keywords Ice storm · Eddy covariance - Subtropical coniferous plantation - Carbon uptake - Southern China

\section{Introduction}

Freezing weather, frequent in temperate regions, sometimes also occurs in the subtropics, where the vegetation is more vulnerable to extremely low temperature. In subtropical southern China, local records show nearly one freezing event there every half a century. Ecosystem losses resulting from increasingly cold weather have drawn attention to the effects of extremely low temperature. Unlike the case in temperate regions, extremely cold weather in the subtropics may bring freezing rain and lead to ecologically harmful glaze ice. Ice accumulation over vegetation often damages forests physically and physiologically. The degree of glaze damage to a forest is controlled by abiotic factors such as weather, topography, vegetation, stand density and management practices (Bragg et al. 2003; Kenderes et al. 2007). Therefore, $\mathrm{Gu}$ et al. (2009) warned that mild winters and warm early springs may induce premature plant development, which then exposes vulnerable plant tissues and organs to subsequent late-season frosts. 
The recovery of forest from freezing influences has been a topic of ecological study (Beaudet et al. 2007; Chaar and Colin 1999; Díaz et al. 2009; Peguero-Pina et al. 2008). The short- and long-term dynamics of trees after one severe frost are determined by a combination of different factors, including species density and spatial distribution, shade tolerance, growth rate, extent of canopy openness and canopy loss (Tremblay et al. 2005). At a regional scale, temporal remote images are suitable for mapping the freezing-induced damage of a forest and monitoring subsequent recovery. La Puma et al. (2007) suggested that gross primary production (GPP) closely follows the pattern of the remote-sensing vegetation index, while the pattern of ecosystem respiration mirrors that of GPP. In addition, remote sensing and environmental data are helpful in discriminating areas with different damage severity (Olthof et al. 2004).

Generally, temperature conditions in southern China are sufficient for local ecosystems. Under the control of the Eastern Asian Monsoon, extremely low temperatures are uncommon in this region, and no glaze ice had been reported in recent decades before 2008. Instead, the local ecosystem is subject to summer drought because of the asynchronism of summer water and heat conditions. Therefore, water deficit in summer and early autumn was thought to be the control factor determining the annual carbon uptake of southern China coniferous plantations (Wen et al. 2010; Yu et al. 2008).

In January 2008, southern China experienced its most severe freezing weather in recent decades. According to ground records, this weather event consisted of a series of unusually severe snowfalls and freezing rains, with extremely low temperature persisting from 11 January to 2 February. During this freezing event, most trees were covered by ice or snow over a period of 2 weeks, and some trees suffered crown loss or bole snapping, or were even uprooted. The air temperature, about $5^{\circ} \mathrm{C}$ below normal during the freezing period, did not rise to normal levels until early March. Coniferous trees, planted extensively during the last 30 years, were affected both physically and physiologically by this weather event. The carbon uptake efficiency of the local forest ecosystem may have been constrained. As freezing events are infrequent in subtropical regions, their influences on forest carbon uptake have been less reported and are not well understood.

This study investigated the freezing-induced carbonuptake loss of a subtropical coniferous plantation at a site in Qianyanzhou (QYZ) in southern China. Data recorded by an eddy covariance system were used to examine possible variations in $\mathrm{CO}_{2}$ flux in 2008. In addition, data obtained in field surveys and remote sensing were used to determine freezing-induced damage to vegetation and subsequent recovery.

\section{Data and methodology}

\subsection{Site description}

The QYZ site in Jiangxi Province of southern China is characterized by a subtropical monsoon climate. The annual air temperature $\left(T_{\mathrm{a}}\right)$ and annual precipitation $(\mathrm{PPT})$ were $17.94^{\circ} \mathrm{C} \pm 0.37^{\circ} \mathrm{C}(\operatorname{mean} \pm \mathrm{SD})$ and $1,505 \pm 312 \mathrm{~mm}$, respectively, during 1989-2008. The subtropical coniferous plantation at this site was planted around 1985 on gently undulating terrain, dominated by slash pine (Pinus elliottii), masson pine (Pinus massoniana) and Chinese fir (Cunninghamia lanceolata). An IKONOS image, acquired on 7 November 2003, shows the land cover at the QYZ site (Fig. 1). The tree density was about 1,460 stems ha ${ }^{-1}$, the biomass was 106 tha $^{-1}$, the leaf area index (LAI) was $5.6 \mathrm{~m}^{2} \mathrm{~m}^{-2}$ and the mean canopy height was about $13 \mathrm{~m}$ (Wen et al. 2006). The red soil was weathered from red sand rock, and the soil texture was categorized as $2.0-0.05 \mathrm{~mm}$ (17\%), 0.05-0.002 mm (68\%) and $<0.002 \mathrm{~mm}(15 \%)$. Further details of the QYZ site are given in Wen et al. (2006).

Under the control of the Eastern Asian Monsoon, the wind directions at the QYZ site bear strong seasonality (Fig. 1). The northwest winter monsoon prevailed during September to April in 2008, while the southeast summer monsoon was not as strong and regulated wind direction only in July and August (Fig. 2). In the period of monsoon transition during May and June, there was no significant dominant wind direction. Therefore, eddy observations of ecosystem $\mathrm{CO}_{2}$ exchange in the winter months would be biased toward the northwest, while that in summer would be slightly biased toward the southeast.

\subsection{Flux measurements and corrections}

An above-canopy flux system at the QYZ site, set at $39.6 \mathrm{~m}$ on a ventilated tower, consists of a three-dimensional sonic anemometer (Model CSAT3, Campbell Scientific, Logan, UT) and an LI7500 open-path $\mathrm{CO}_{2} / \mathrm{H}_{2} \mathrm{O}$ analyzer (Model LI-7500, Li-Cor, Lincoln, NE). Flux variables were sampled at $10 \mathrm{~Hz}$ using a CR5000 datalogger (Model CR5000, Campbell Scientific), from which 30-min average fluxes were calculated. This eddy system could sense $\mathrm{CO}_{2}$ exchange over a footprint with a peak contribution about $500 \mathrm{~m}$ from the flux tower. Under the control of typical monsoons, the forest between $200 \mathrm{~m}$ and $800 \mathrm{~m}$ from the tower in the northwest and southeast contributed more to eddy measurements (Mi et al. 2006).

A four-component net radiometer (Model CNR-1, Kipp \& Zonnen, Delft, the Netherlands), pyranometer (Model CM11, Kipp \& Zonen) and quantum sensor of photosynthetically active radiation (Model LI190SB, Li-Cor) were 
Fig. 1 IKONOS image of the region around the Qianyanzhou (QYZ) flux tower (red point). The filled orange patches are severely damaged areas, the red polygon is the wind direction rose, and the interval between concentric circles is $200 \mathrm{~m}$

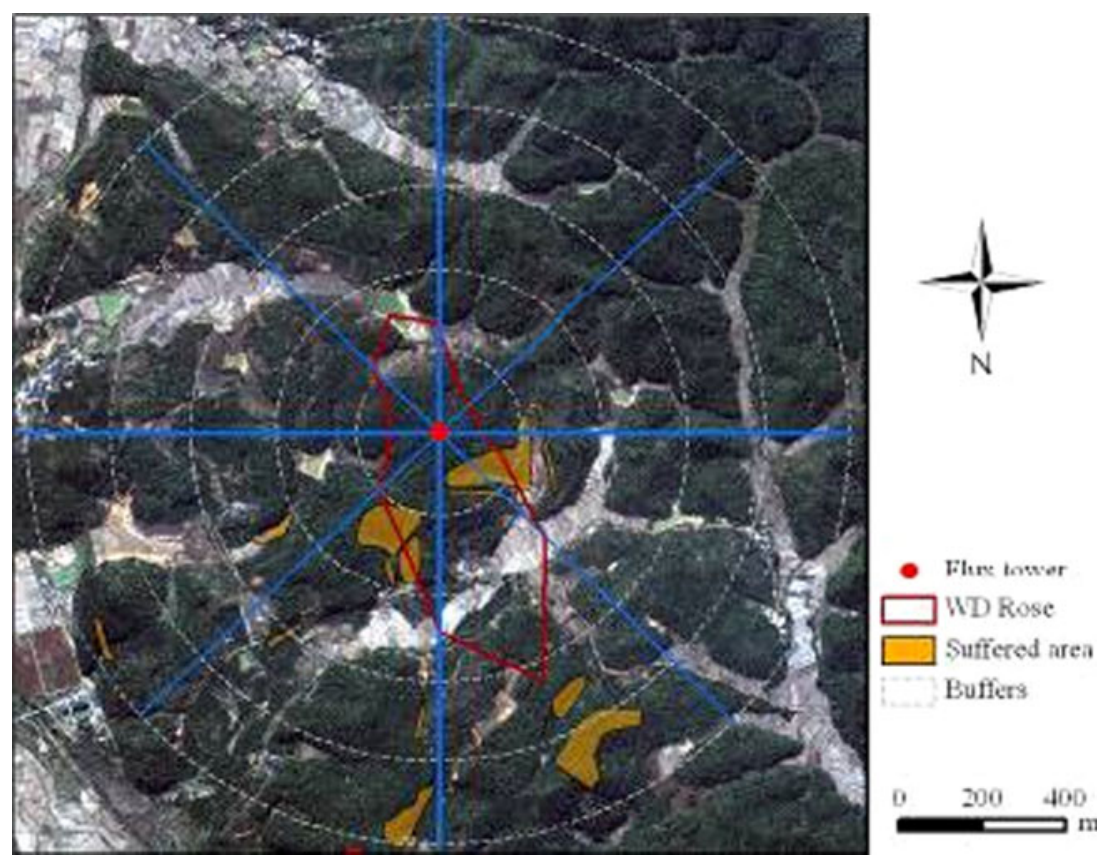

used to measure routine meteorological conditions. Seven sets of air-temperature and relative humidity sensors (Model HMP45C, Campbell Scientific) were mounted on the ventilated tower at different heights. Soil temperatures were measured at five depths $(2,5,20,50$ and $100 \mathrm{~cm})$ with thermocouples (105 T and 107-L, Campbell Scientific), while soil water content was recorded with three timedomain reflectometer probes (Model CS615-L, Campbell Scientific) at depths of 5,20 and $50 \mathrm{~cm}$. Rainfall was monitored with a rain gauge (Model 52203, RM Young, Traverse City, MI). The data were collected by three CR10X dataloggers (Model CR10XTD, Campbell Scientific) and one CR23X datalogger (Model CR23XTD, Campbell Scientific) with a 25-channel solid-state multiplexer (Model AM25T, Campbell Scientific).
The net ecosystem $\mathrm{CO}_{2}$ exchange (NEE, $\mathrm{mg} \mathrm{CO}_{2} \mathrm{~m}^{-2} \mathrm{~s}^{-1}$ ) between the ecosystem and the atmosphere was calculated with Eq. (1), and the ecosystem productivity was assigned to -NEE.

$N E P=-\left(\overline{w^{\prime} \rho_{c}^{\prime}\left(z_{r}\right)}+\int_{0}^{z_{r}} \frac{\partial \overline{\rho_{c}}}{\partial t} d z\right)$

where the first term on the right is the eddy flux for carbon dioxide and the second is the storage below the observation height $\left(z_{\mathrm{r}}\right)$. All advective terms in the mass conservation equation were ignored. Spurious observations were removed when instrument performance and experimental conditions were abnormal (e.g., at times of rainfall, water condensation or system failure). Calculation of the $30-\mathrm{min}$ average, using a window of $18,00010-\mathrm{Hz}$ values, excluded some physically impossible values (Wen et al. 2009).
Fig. 2 Monthly wind direction frequencies at the QYZ site in 2008

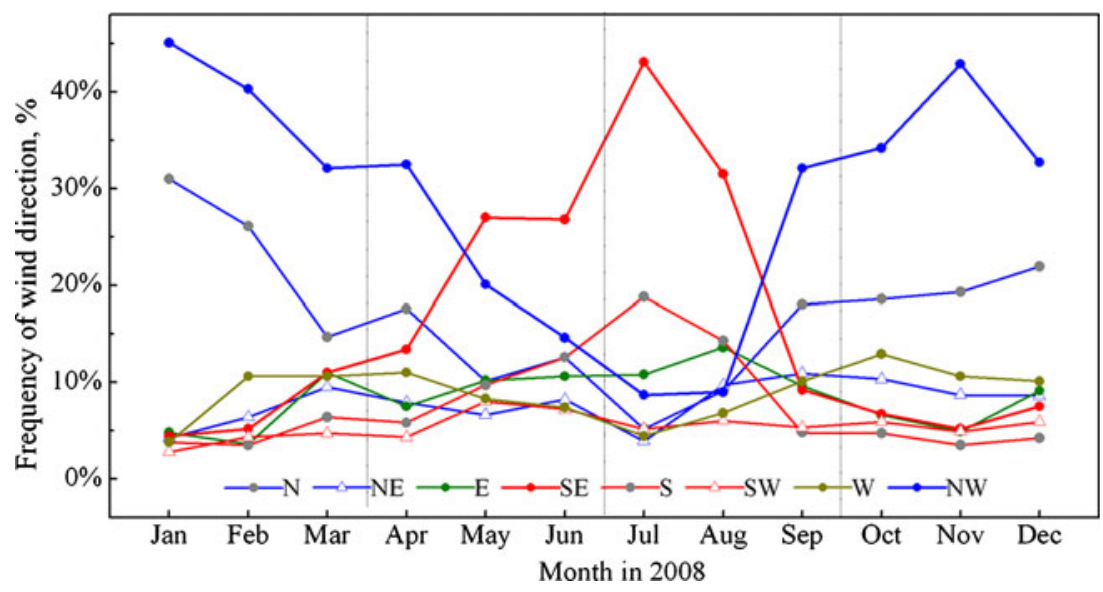


For the time series of half-hour data points, planar rotation was applied to the wind components to remove the effects of instrument tilt and irregularity on the airflow at monthly intervals (Wilczak et al. 2001). The quality and reliability of flux measurements were examined using power spectra and co-spectra (Sun et al. 2006). Instrument effects that dampen the high-frequency fluctuations were corrected, including dynamic frequency responses of the sonic anemometer and the infrared gas analyzer, scalar path averaging and sensor separation (Aubinet et al. 1999). The Webb-Pearman-Leuning method was employed to correct the effect of air density fluctuations on $\mathrm{CO}_{2}$ fluxes (Webb et al. 1980). The influence of $\mathrm{CO}_{2}$ storage below the observation height was adjusted with the temporal change in $\mathrm{CO}_{2}$ concentration above the canopy (Yu et al. 2008). According to the examination of steady state and integral turbulence characteristics, an overall quality flag was created for $\mathrm{CO}_{2}$ flux (Aubinet et al. 1999). The spike detecting method of Papale et al. (2006) was then used separately for 13-day blocks of daytime and nighttime $\mathrm{CO}_{2}$ flux data. To prevent the possible underestimation of $\mathrm{CO}_{2}$ fluxes due to weak turbulence, values recorded when the friction velocity $\left(\mathrm{u}^{*}\right)$ was less than $0.19 \mathrm{~ms}^{-1}$ at night (global radiation less than $1 \mathrm{Wm}^{-2}$ ) were rejected (Reichstein et al. 2005).

\subsection{Gap filling and flux partitioning}

For long-term series of flux data, occasional gaps are unavoidable because of calibration or equipment failure. With quality control measures carried out at half-hourly intervals, there were $30-35 \%$ and $85-90 \%$ data missing in the flux collections during the day and night, respectively. However, the data gaps can be reconstructed with associated meteorological measurements (Falge et al. 2001; Papale and Valentini 2003; Richardson et al. 2006). The present study employed the nonlinear regression method (Moffat et al. 2007; Richardson and Hollinger 2007) to fill the long data gaps $(>2 \mathrm{~h})$, where missing daytime NEP was estimated using the Michaelis-Menten equation with a 10-day window:

$N E P=\frac{\alpha N_{e s} Q_{p}}{N_{e s}+\alpha Q_{p}}-R E_{d a y}$,

where $\alpha$ is the ecosystem apparent quantum yield ( $\mathrm{mg}$ $\left.\mathrm{CO}_{2} \mu \mathrm{mol}^{-1}\right), Q_{\mathrm{p}}$ is the photosynthetic photon flux density $\left(\mu \mathrm{mol} \mathrm{m} \mathrm{m}^{-2} \mathrm{~s}^{-1}\right), N_{\mathrm{es}}$ is the asymptotic gross ecosystem production (GEP; $\mathrm{mg} \mathrm{CO} \mathrm{CO}_{2} \mathrm{~m}^{-2} \mathrm{~s}^{-1}$ ) for a saturated light condition, and $\mathrm{RE}_{\mathrm{day}}$ is the average daytime ecosystem respiration (RE; $\mathrm{mg} \mathrm{CO}_{2} \mathrm{~m}^{-2} \mathrm{~s}^{-1}$ ).

In the case of nighttime data, NEP was defined as ecosystem respiration $\left(\mathrm{RE}_{\text {night }} ; \mathrm{mg} \mathrm{CO}_{2} \mathrm{~m}^{-2} \mathrm{~s}^{-1}\right)$. Missing
$\mathrm{RE}_{\text {night }}$ data were estimated using the relationship of $\mathrm{RE}$ with the soil temperature and soil water content (Reichstein et al. 2002):

$R E_{\text {night }}=R E_{\text {ref }}\left(b_{1}+b_{2} S_{W}\right)^{\frac{T_{\text {soil }}-T_{\text {ref }}}{10}}$,

where $R_{\text {ref }}, b_{1}$ and $b_{2}$ are the fitted parameters, $R_{\text {ref }}$ is the RE rate $\left(\mathrm{mg} \mathrm{CO}_{2} \mathrm{~m}^{-2} \mathrm{~s}^{-1}\right)$ at reference temperature $T_{\text {ref }}$ (set as $15^{\circ} \mathrm{C}$ here), and $S_{\mathrm{w}}$ and $T_{\text {soil }}$ are the soil water content $\left(\mathrm{m}^{3} \mathrm{~m}^{-3}\right)$ and the soil temperature, respectively. To estimate daily GEP, the daytime ecosystem respiration $\left(\mathrm{RE}_{\text {day, }}\right)$ was estimated by extrapolating the nighttime relationship of ecosystem respiration $\left(\mathrm{RE}_{\text {night } t}\right)$ with the soil temperature and water content.

\subsection{Field survey}

The influences on local subtropical forests of freezing weather in 2008 can be categorized as two types: physical damage caused by ice accumulation over branches or canopies, and physiological injuries caused by extremely low temperature $\left(\sim 5^{\circ} \mathrm{C}\right.$ below normal). The freezinginduced injuries to the QYZ forest were surveyed in February and March of 2008. The species of damaged trees, injury severity and the distribution of areas affected were thoroughly categorized (Ma et al. 2010). In September 2008, a field survey of freezing-induced forest gaps was carried out to monitor ecosystem recovery. Physical injuries within a $1-\mathrm{km}$ radius of the flux tower were plotted on an IKONOS image (Fig. 1).

\subsection{Remotely sensed vegetation index}

A long time-series of the remotely sensed vegetation index reflects the temporal above-ground growth variation of a plantation (Churkina et al. 2005). The 16-day enhanced vegetation index (EVI) of the Moderate Resolution Imaging Spectroradiometer (MODIS) for the period 2003-2008 was acquired from the NASA Data Gateway (NASA 2009). Compared with the widely used normalized difference vegetation index, the EVI is more resistant to soil background, less susceptible to atmospheric disturbance and less sensitive to vegetation saturation (Huete et al. 2002). This EVI product is available at resolutions of $500 \mathrm{~m}$ and 16 days. The temporal EVI was extracted for the $1-\mathrm{km}$ region around the flux tower (Fig. 1). The forest fraction of this region exceeded $80 \%$.

The MODIS EVI was produced with the 16-day maximum values, but this does not completely remove the influences of cloud contamination, instrument failure and algorithm limitations (Huete et al. 2002). The SavitzkyGolay method was adopted to detect and replace the physically impossible EVI values. This filter performs local 
polynomial regression to determine the smoothed value for each data point (Savitzky and Golay 1964). In this study, the two key parameters of the Savitzky-Golay filter, the smoothing polynomial degree and window length, were set as 2 and 5 , respectively.

\section{Results}

\subsection{Environmental conditions}

During the 2008 freezing period (from 11 January to 2 February), the air temperature was persistently about $5^{\circ} \mathrm{C}$ below normal (Fig. 3a). The QYZ site experienced a series of severe snowfalls and freezing rains during this extremely cold period and the vegetation was covered by glaze ice for more than 15 days. The low temperature persisted for longer than a month (Fig. 3a). However, in the remaining months of 2008, the air temperature and precipitation were basically within normal variations. Figure $3 \mathrm{a}$ also indicates a cold spring in 2005 . Although not as cold $\left(2-3^{\circ} \mathrm{C}\right.$ below normal) as in 2008, the cold temperature in 2005 persisted for a longer period (> 2 months).

A cold winter and spring are not usual at the subtropical QYZ site. The months of January in 1993, 2005 and 2008 were the three coldest during the last two decades, and the coldest month of February was in 2008 (Fig. 4). In addition, freezing rains caused glaze ice in January and February 2008 , which is unprecedented in last 50 years. The eddy flux observations during 2003-2008 would be helpful in investigating the effects of freezing weather on ecosystem carbon uptake.
There was no distinct variation in solar radiation in 2008 (Fig. 5). The generally normal environmental conditions in 2008 except for the freezing duration help facilitate examination of the effects of glaze ice on ecosystem carbon uptake. In addition, Fig. 5 indicates that annual solar radiation was about $10 \%$ below normal $\left(\sim 400 \mathrm{MJ} \mathrm{m}^{-2}\right)$ in 2005 and 2006. The distinct radiation decline in January and February led to cold weather in the early months of 2005 (Fig. 3a), and the radiation level was moderately but persistently below normal throughout the remainder of 2005. In 2006, the first half of the year also experienced a moderately low level of solar radiation, but the radiation was basically at a normal level from late July to November.

\subsection{Forest damage}

The field surveys showed freezing-induced plantation damage of different severity at the QYZ site. The affected areas were distributed mostly at the forest edges, roadsides and valley banks (Fig. 1), where wind speeds would have been higher. In field surveys, a tree was recorded as severely damaged if either it lodged, its bole snapped or more than $50 \%$ of its canopy branches were broken. The damage ratio was expressed as the percentage of damaged stems. The survey showed that, within $500 \mathrm{~m}$ of the flux tower, about $10 \%$ of trees were destroyed by glaze ice, while the damage ratio for the whole QYZ site was about $6 \%$. The average losses in above-ground biomass and plant carbon in severely damaged areas were 2,841 and $1,467 \mathrm{~g} \mathrm{~m}^{-2}$, respectively, and corresponding losses for the whole QYZ site were, on average, 441 and $227 \mathrm{gm}^{-2}$ (Table 1). If the winter footprint between 200 and $800 \mathrm{~m}$
Fig. 3 Ten-day averaged environmental conditions at the QYZ site for 2003-2008. a Air temperature $\left(T_{\mathrm{a}},{ }^{\circ} \mathrm{C}\right)$, b precipitation (PPT, mm). Bars and curves are 10-day averaged measurements and corresponding multi-year averages, respectively

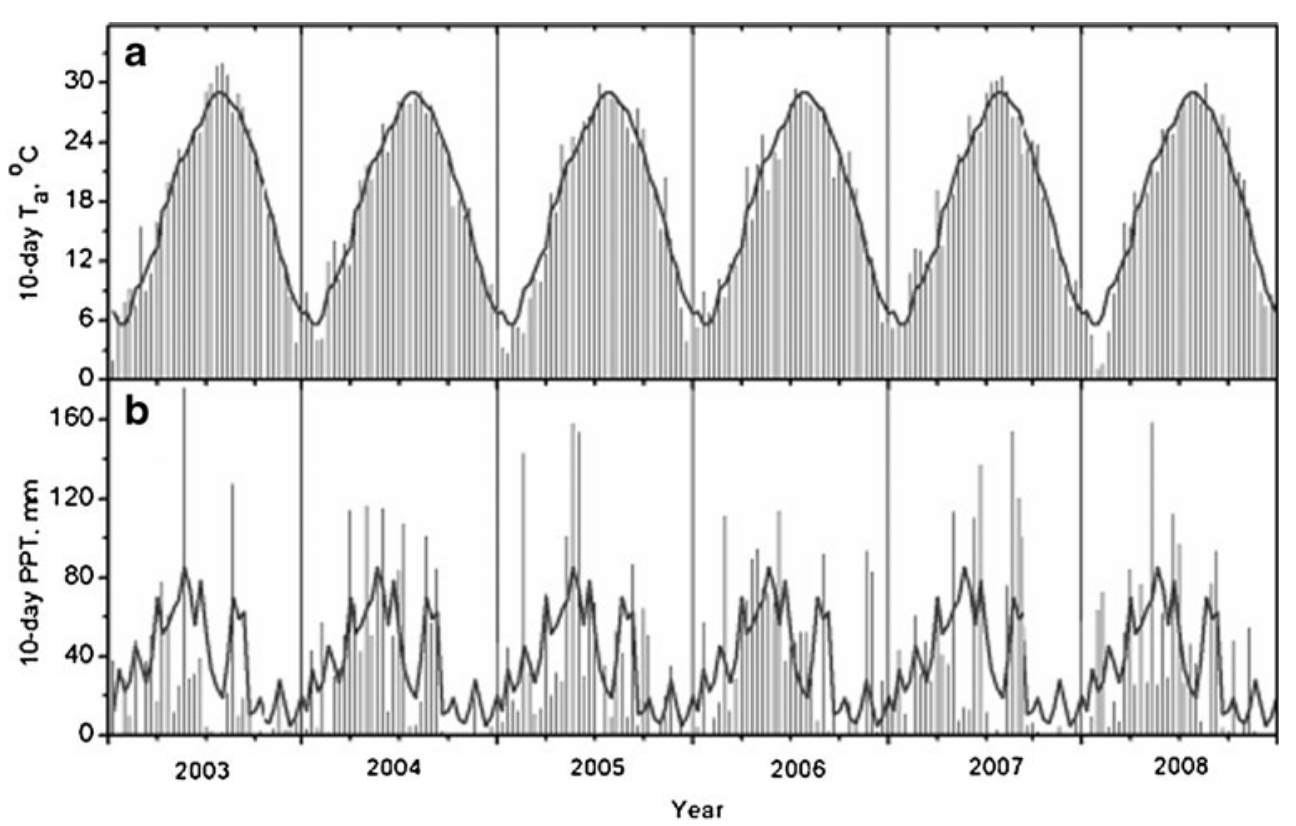


Fig. 4 Monthly averaged air temperature $\left(T_{\mathrm{a}}\right)$ for January to March at the QYZ site during 1989-2008

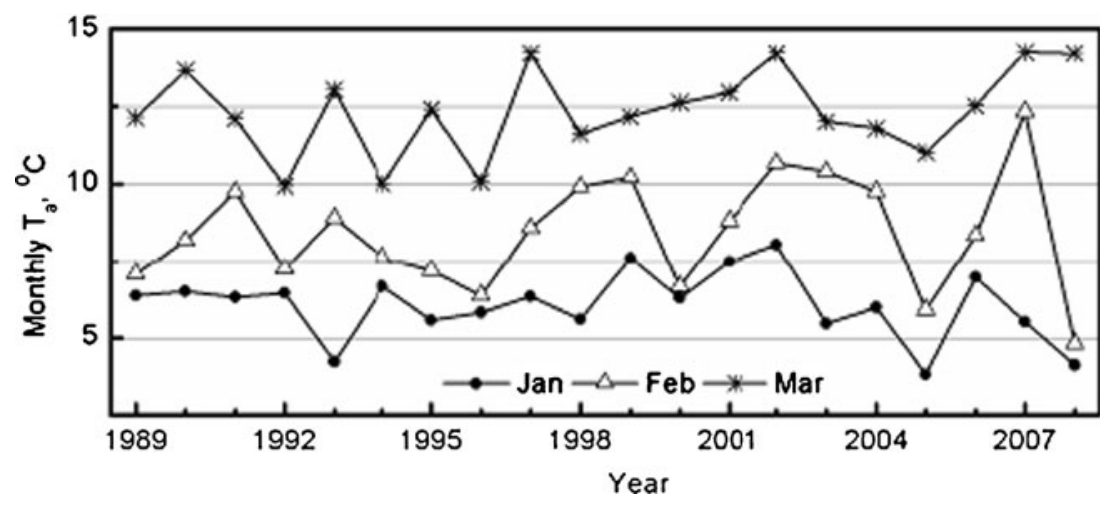

from the tower in the north and northwest directions were estimated, the damage ratio would be greater than $15 \%$. During the freezing weather, the wind direction was highly concentrated in the northwest and north directions, and the northern footprint (i.e., the windward region) was thus more susceptible to freezing rains and glaze ice. Within $500 \mathrm{~m}$ of the flux tower, slash pine was damaged far more severely than other tree species. This could be attributed to its ellipsoid canopy, long needles (susceptible to ice accumulation) and weak lateral root system.

A field survey carried out in September 2008 observed the rapid growth of shrubs and grasses in forest gaps resulted from freezing. The fraction of forest cover was over $80 \%$ in the flux tower region before the freezing event, and the growth of understory vegetation had been severely constrained. However, the improved radiation conditions in forest gaps greatly promoted understory growth. This rapid understory growth partially compensated for the ecosystem production loss caused by damaged trees.

\subsection{Vegetation index variation}

The EVI curve depression in the early months of 2008 reflected the phenological lag during the whole year (Fig. 6). The averaged January-March EVI of the 1-km tower region in $2008(0.223)$ was significantly $(P=0.002)$ lower than normal $(0.258$, with 2005 excluded). The EVI curve of 2008 exhibited a phenological lag of about 10 days, and a low spring EVI and temporal lag were also observed in 2005 (Fig. 6). Although the EVI depressions related to low temperature in 2005 and 2008, the underlying reasons were not similar. The extremely low $T_{\mathrm{a}}$ and glaze ice in 2008 caused both physiological and physical damage to vegetation, while the phenological lag in 2005 was the result of the persistent but moderately low $T_{\mathrm{a}}$. However, the EVI in the remaining months of 2005 and 2008 was generally at a normal level. In addition, Fig. 6 indicates a slight depression in the EVI curves during the summer and early autumn of 2003 when the QYZ site experienced a water deficit.
Fig. 5 Seven-day slidingaveraged daily downward solar radiation $\left(R_{\mathrm{S}}\right)$ and accumulative $R_{\mathrm{S}}$ deviation relative to normal daily levels during 2003-2008

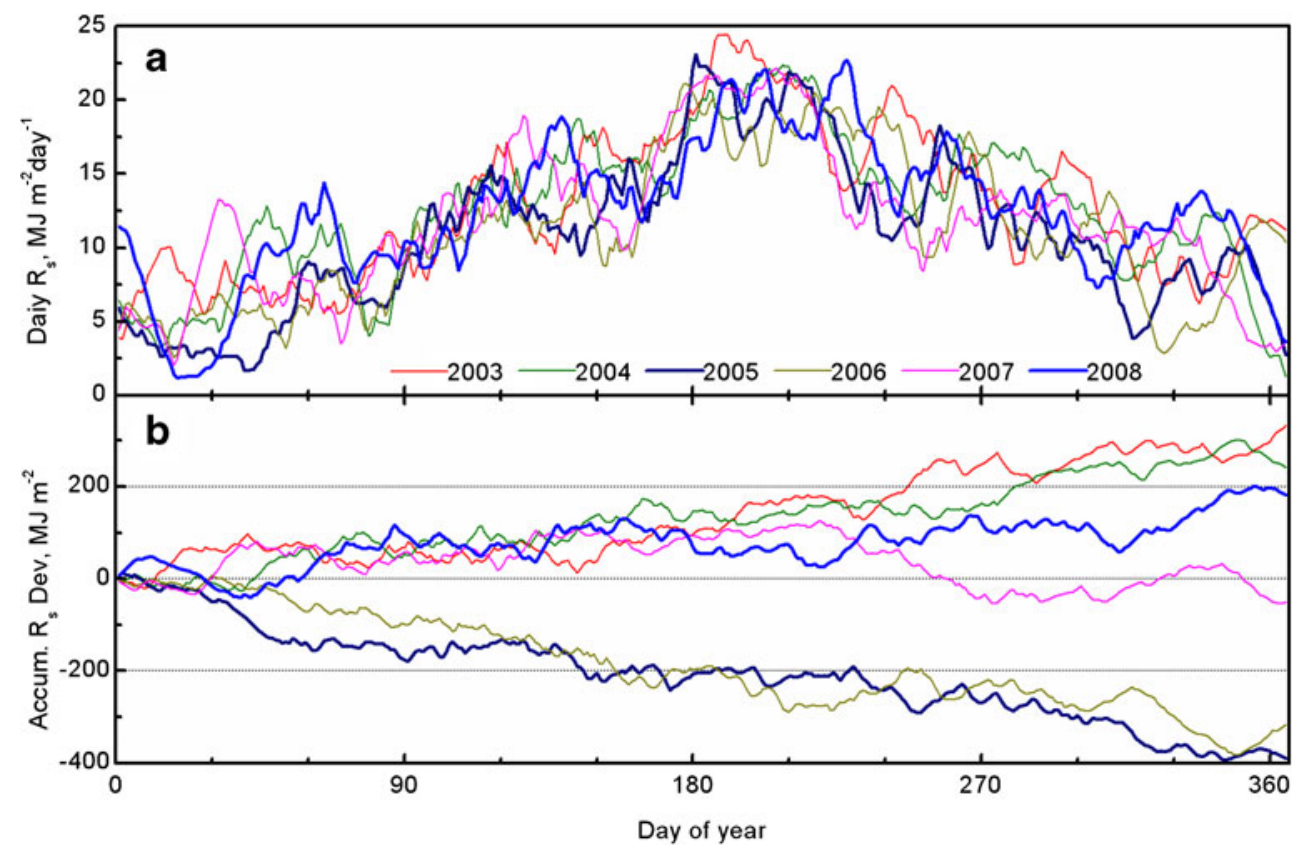


Table 1 Losses of above ground biomass and vegetation carbon caused by glaze damage at the QYZ site (compiled from Ma et al. 2010)

\begin{tabular}{lllll}
\hline & Area $\left(\mathrm{hm}^{-2}\right)$ & Damage ratio (\%) & $\begin{array}{l}\text { Biomass loss } \\
\left(\mathrm{g} \mathrm{m}^{-2}\right)\end{array}$ & $\begin{array}{l}\text { Carbon loss } \\
\left(\mathrm{g} \mathrm{m}^{-2}\right)\end{array}$ \\
\hline Severely damaged region & 7.72 & $>50$ & 2,841 & 1,462 \\
Moderately or little damaged region & 118.46 & $<50$ & 389 & 200 \\
QYZ site & 126.18 & $<5$ & 441 & 227 \\
\hline
\end{tabular}

\subsection{Response of carbon uptake}

The annual carbon uptake of the QYZ ecosystem in 2008 was distinctly less than normal years without climate anomalies $\left(\sim 400 \mathrm{gC} \mathrm{m}^{-2}\right.$ year $\left.^{-1}\right)$. Ecosystem respiration in 2008 did not deviate significantly from normal $\left(\sim 1,390 \mathrm{gC} \mathrm{m}^{-2}\right.$ year $\left.^{-1}\right)$, but the large decrease in photosynthesis resulted in a distinct decrease in carbon sequestration (Table 2). The annual NEP in $2008\left(316 \mathrm{gC} \mathrm{m}^{-2}\right)$ was about $66 \mathrm{gC} \mathrm{m}^{-2}$ below average, and was only slightly above the least annual NEP $\left(306 \mathrm{gC} \mathrm{m}^{-2}\right)$ recorded in 2005. The opposite deviations in annual GEP (negative) and annual $\mathrm{RE}$ (positive) in 2008 led to the highest RE/GEP ratio (0.820) within the last 6 years. This high RE/GEP ratio suggests a dampening effect of the 2008 freezing weather on carbon uptake efficiency.

The curves of daily $\mathrm{CO}_{2}$ fluxes and the accumulative deviations illustrate the carbon uptake response of the QYZ ecosystem to the 2008 freezing weather (Fig. 7). The deviations were calculated as the difference between the daily carbon fluxes and corresponding averages during 2003-2008. The accumulative curves reflected quite different patterns for the first half and second half of 2008. Influenced by the freezing weather, the accumulative GEP deviated negatively until mid-July (DOY190) in 2008 (reaching $-75 \mathrm{gC} \mathrm{m}^{-2}$ ), but then increased continuously in the remaining months. Therefore, the annual GEP decline in $2008\left(-24 \mathrm{gC} \mathrm{m}^{-2}\right)$ was much less than the

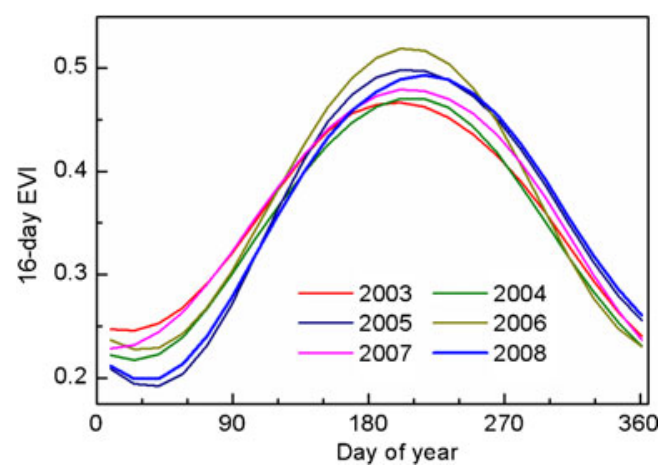

Fig. 6 Temporal MODIS EVI curves from a 1-km region surrounding the QYZ flux tower during 2003-2008. The curves for 2005 and 2008 reflect a significant phenological lag decline in the first half of the year because of the compensation of the high photosynthesis rate in the second half of the year. On the other hand, the RE rate during the first half of 2008 fluctuated moderately around a normal level, while it was about $50 \mathrm{gC} \mathrm{m}^{-2}$ above normal ( $\sim 790 \mathrm{gC} \mathrm{m}^{-2}$ year $\left.^{-1}\right)$ in the reminder of 2008. The strong GEP decline and the slight RE variation in the first half of 2008 led to a distinct reduction in carbon uptake (about $-60 \mathrm{gC} \mathrm{m}^{-2}$ ), but the comparable positive variations in GEP and RE fluxes caused only moderate NEP fluctuation in the second half of the year (Fig. 7d). The high levels of photosynthesis and ecosystem respiration in the second half of 2008 implied partial ecosystem recovery from the freezing-induced disturbances.

Daily $\mathrm{CO}_{2}$ fluxes in 2005 varied quite differently from those in 2008 (Fig. 7). The persistent low temperature in the early months of 2005 resulted in a phenological lag for local vegetation (Fig. 6), and thus low rates of GEP and RE. However, solar radiation, below normal throughout nearly the whole year of 2005, further restrained the photosynthesis and autotrophic respiration of the QYZ ecosystem. Therefore, both GEP and RE fluxes were basically below normal levels throughout 2005, and the stronger deviation in GEP compared to RE led to persistent NEP depression in 2005 (Fig. 7d).

The variation in the quarterly RE/GEP ratios in 2008 also reflects the gradual ecosystem recovery from the freezing influences. Although the annual RE/GEP ratio of 2008 was the highest during 2003-2008, the difference in the quarterly RE/GEP ratios between 2008 and other years decreased gradually from 0.10 to 0.02 (Fig. 8). In the fourth quarter, the RE/GEP ratio of 2008 returned to almost the level for other years (2005 excluded). During ecosystem recovery, the levels of photosynthesis and autotrophic respiration would have increased with time, while heterotrophic respiration would have been less influenced by recovery. This variation in the RE/GEP ratio was consistent with the differences in flux deviation between the two half-year periods of 2008, implying the gradual restoration of ecosystem production from freezing disturbance. However, the quarterly RE/GEP ratio had a different variation with time in 2005. The ratios in 2005 were distinctly above normal except for that of the third quarter (Fig. 8). 
Table 2 Annual fluxes of ecosystem carbon exchange at the QYZ site during 2003-2008 $\left(\mathrm{CO}_{2}\right.$ flux, $\left.\mathrm{g} \mathrm{Cm}^{-2}\right)$. GEP Gross ecosystem production, $R E$ respiration, $N E P$ net ecosystem productivity

\begin{tabular}{llllllll}
\hline & 2003 & 2004 & 2005 & 2006 & 2007 & 2008 & Mean \\
\hline GEP & 1,702 & 1,856 & 1,629 & 1,851 & 1,857 & 1,754 & 1,775 \\
RE & 1,286 & 1,446 & 1,323 & 1,440 & 1,427 & 1,437 & 1,393 \\
NEP & 416 & 411 & 306 & 412 & 430 & 316 & 382 \\
RE/GEP & 0.755 & 0.779 & 0.812 & 0.778 & 0.768 & 0.820 & 0.785 \\
\hline
\end{tabular}

\section{Discussion}

4.1 Influences of low temperature and glaze ice on carbon uptake

The extremely low temperature in 2008 severely damaged the subtropical plantation ecosystem, although a moderately cold spring alone would not necessarily reduce annual carbon uptake significantly. The lowest annual GEP $\left(1,629 \mathrm{gC} \mathrm{m}^{-2}\right)$ and the second-lowest annual $\mathrm{RE}$ $\left(1,323 \mathrm{gC} \mathrm{m}^{-2}\right)$ of the last 6 years occurred in 2005 , which resulted in the lowest annual NEP $\left(306 \mathrm{gC} \mathrm{m}^{-2}\right)$. Although the persistent low temperature of early 2005 resulted in a phenological lag as observed in 2008 (Fig. 6), the year-long low level of solar radiation further restrained the GEP and $\mathrm{RE}$ rates in 2005 .

On the other hand, the influence of glaze ice on forests may be complicated. Ice accumulation over leaves, branches and trunks could cause physical damage, such as crown loss, bole snapping, and even uprooting. The glaze ice also could aggravate the chilling effect of cold weather, which would further retrain vegetation activity. In addition, leaves and branches would be partially or completely isolated from the atmosphere by the glaze ice. Exchanges of oxygen, carbon dioxide and water between vegetation and atmosphere would thus be greatly restricted. Therefore, photosynthesis and autotrophic respiration would be dormant to a degree during the glaze period.

The loss of carbon uptake in 2008 resulted from the combination of physical damage caused by glaze ice and physiological injuries caused by extremely low temperature, while the loss in carbon uptake in 2005 was caused mainly by the year-long low radiation level and the moderately cold spring. In addition, although the low radiation level led to a loss in carbon uptake in the first half of 2006, this was nearly counteracted by an uptake gain in the second half of that year under normal environmental conditions.
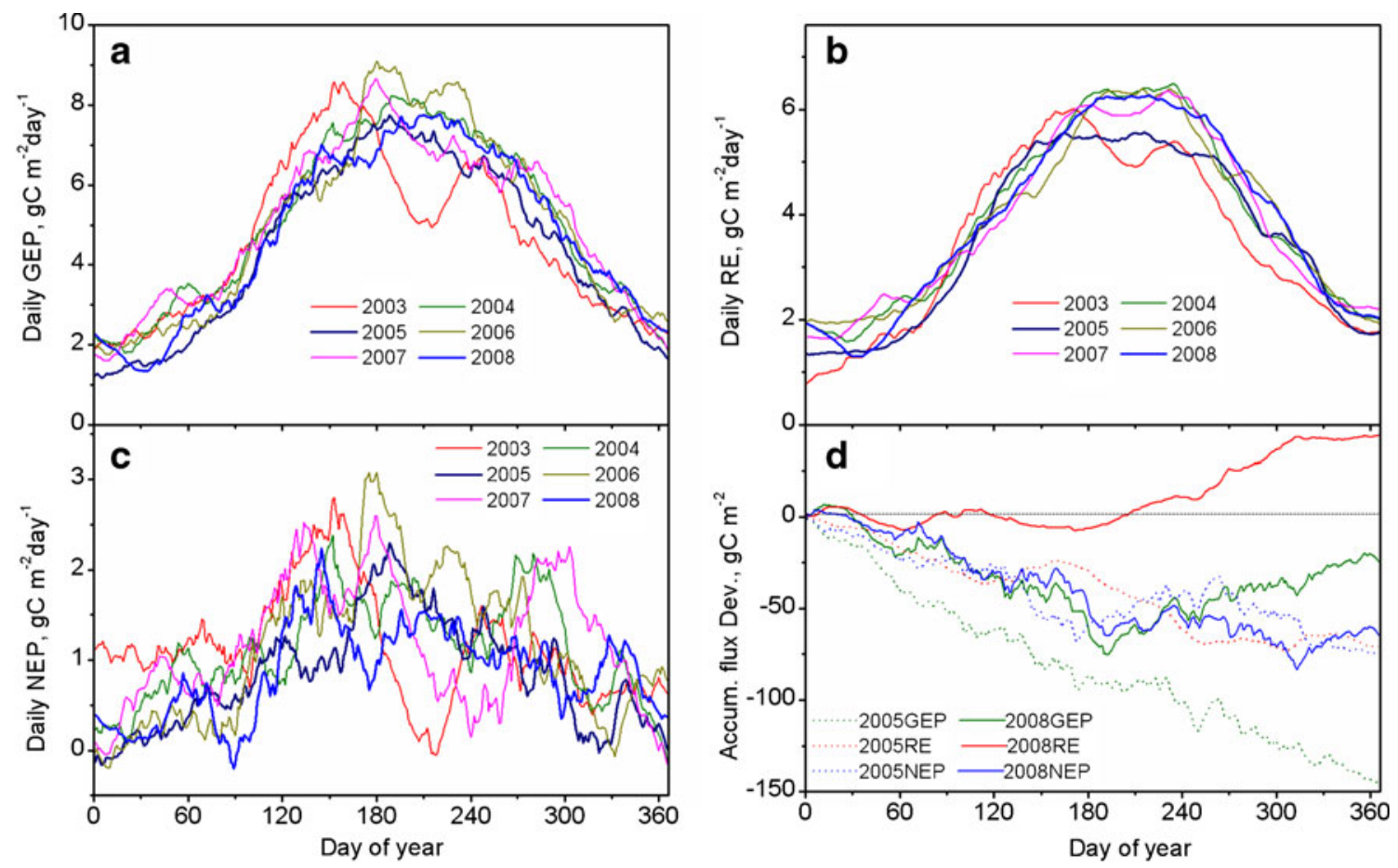

Fig. 7 Daily $\mathrm{CO}_{2}$ fluxes during 2003-2008 (a-c) and the accumulative deviations from normal levels during 2005 and 2008 (d) 
Fig. 8 Quarterly respiration/ gross ecosystem production (RE/GEP) ratios for 2005 and 2008 (columns) and the ratio deviation for 2008 from the average of 2003-2007 with 2005 excluded (Dev2008, curve)

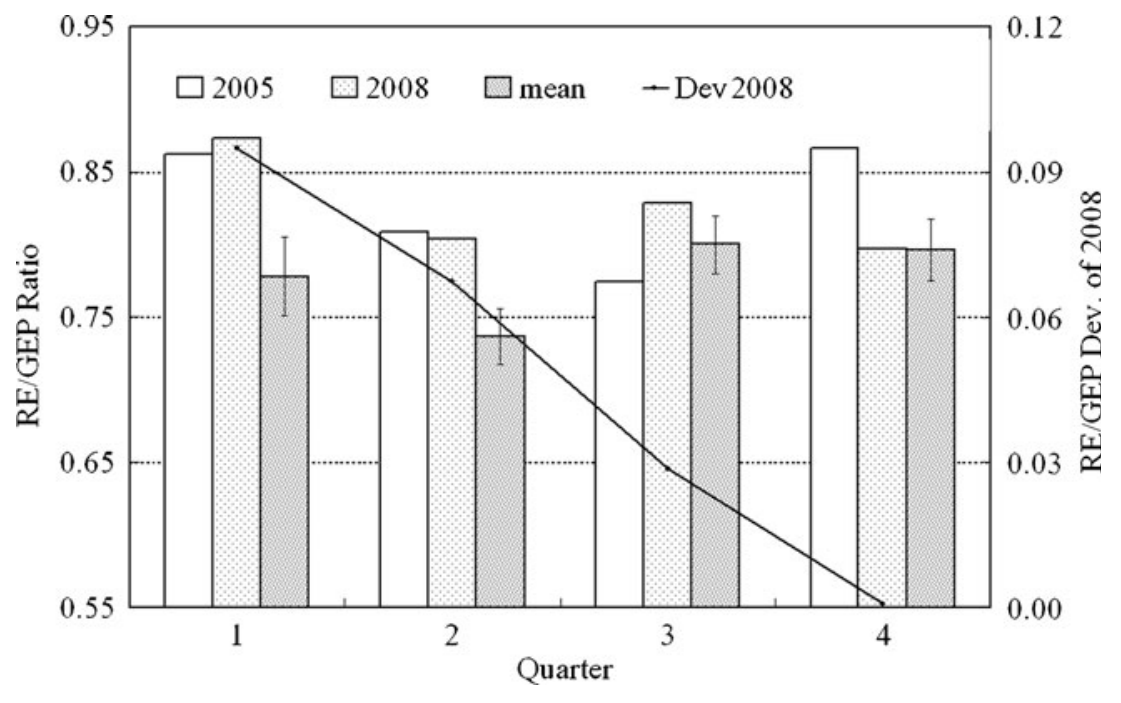

\subsection{Footprint biases caused by monsoons}

The flux variations and subsequent recovery dynamics in 2008 indicated by the eddy measurements were possibly subject to footprint biases caused by monsoons. The QYZ site was alternately dominated by summer and winter monsoons. The observed eddy $\mathrm{CO}_{2}$ fluxes during the 2008 freezing period and the subsequent month would be biased toward the north, where trees were severely affected by glaze ice (Fig. 1). On the contrary, the flux observation in the 2008 summer was biased slightly to the south, i.e., the less-influenced area. Therefore, the loss in carbon uptake during the early months of 2008, and ecosystem recovery during the summer months were possibly overestimated by the flux observations.

However, the conclusion of gradual ecosystem recovery from glaze-damage still holds true. The eddy observations show the significant recovery of photosynthesis from July 2008 (Fig. 7), when the measurements were biased towards the lightly-glaze-influenced southeast footprint under the control of the summer monsoon. Therefore, the eddy-systemobserved "recovery" of the QYZ forest from glaze damage partially included a false "recovery", because the footprint during July and August comprised mainly the lightly influenced southern forest patches. From September to December, when the eddy observations were biased toward the severely damaged forest patches, both photosynthesis and ecosystem respiration were above normal levels (Fig. 7). This finding of high GEP and RE levels from September to December in 2008 reflects the recovery of the carbon uptake capability of the glaze-damaged plantation patches.

4.3 Carbon uptake depressed by physical and physiological injuries

The influences of the 2008 freezing weather on the subtropical ecosystem include physical damage due to glaze ice and physiological effects. The physiological injuries, which are due to extremely low temperatures, may heal gradually when environmental conditions normalize. However, leaves, branches, canopies and even whole trees that are physically destroyed need a longer time to renew or be reestablished by understory shrubs and grasses. To discriminate the losses in carbon uptake caused by physical and physiological injuries, both the loss of overstory stands and the gain of understory growth should be surveyed or estimated. One comparably cold spring without glaze ice is necessary to evaluate the physiological injuries of the subtropical ecosystem. The temperature in the early months of 2005 was not as low as that in 2008, and the QYZ ecosystem in 2005 was subject to radiation constraints. Therefore, the losses in carbon uptake resulting from low temperatures in 2005 and 2008 were not comparable.

\section{Conclusion}

Using eddy covariance observation, field surveys and remotely sensed EVI, we investigated the freezinginduced loss in carbon uptake of a subtropical coniferous plantation ecosystem in 2008 at the QYZ site, southern China. The following conclusions were drawn.

(1) Field surveys showed that more than $6 \%$ of trees at the QYZ site (especially slash pine) were destroyed, and the trees at the forest edges and valley banks were particularly susceptible to damage from glaze ice. The curve of the remotely sensed EVI indicated a phenological lag of 10 days in 2008 due to the freezing weather.

(2) The RE rate for 2008 did not deviate significantly from normal levels, but the strong decline in GEP led to a significant loss in carbon uptake $\left(\sim 66 \mathrm{gC} \mathrm{m}^{-2}, 17 \%\right.$ of 
annual uptake). The loss was a result of both the physical damage caused by glaze ice and physiological injuries caused by the extremely low temperature.

(3) Although the annual RE/GEP ratio of 2008 was the highest in the last 6 years, the difference in quarterly RE/GEP ratios between 2008 and other years decreased gradually from 0.10 to 0.02 , reflecting ecosystem recovery with time.

(4) Because the eddy flux footprint was biased towards the lightly influenced forest patches under the control of the southeast summer monsoon during July and August, the flux observations in 2008 possibly overestimated carbon uptake loss in the early months and ecosystem recovery during summer months.

Acknowledgments This work was supported financially by the Ministry of Science and Technology of China (2009CB421101), the National Natural Science Foundation of China (30870444, 40801175), the Knowledge Innovation Project of Chinese Academy of Sciences (KZCX2-YW-Q1-14), the Hundred Talents Program of Chinese Academy of Sciences and the China Postdoctoral Science Foundation (20100470536).

\section{References}

Aubinet M, Grelle A, Ibrom A, Rannik Ü, Moncrieff J, Foken T, Kowalski AS, Martin PH, Berbigier P, Bernhofer C, Clement R, Elbers J, Granier A, Grünwald T, Morgenstern K, Pilegaard K, Rebmann C, Snijders W, Valentini R, Vesala T (1999) Estimates of the annual net carbon and water exchange of forests: the EUROFLUX methodology. Advances in Ecological Research. Academic, New York, pp 113-175

Beaudet M, Brisson J, Gravel D, Messier C (2007) Effect of a major ice storm on understory light conditions in an old-growth AcerFagus forest: pattern of recovery over seven years. For Ecol Manag 242:553-557

Bragg DC, Shelton MG, Zeide B (2003) Impacts and management implications of ice storms on forests in the southern United States. For Ecol Manag 186:99-123

Chaar H, Colin F (1999) Impact of late frost on height growth in young sessile oak regenerations. Ann For Sci 56:417-429

Churkina G, Schimel D, Braswell BH, Xiao Xl (2005) Spatial analysis of growing season length control over net ecosystem exchange. Glob Chang Biol 11:1777-1787

Díaz R, Johnsen Ø, Fernandez-Lopez J (2009) Variation in spring and autumn freezing resistance among and within Spanish wild populations of Castanea sativa. Ann For Sci 66:708

Falge E, Baldocchi D, Olson R et al (2001) Gap filling strategies for defensible annual sums of net ecosystem exchange. Agric For Meteorol 107:43-69

Gu L, Hanson PJ, Mac Post W, Kaiser DP, Yang B, Nemani R, Pallardy SG, Meyers T (2009) The 2007 eastern US spring freeze: increased cold damage in a warming world. BioScience $58: 253-262$

Huete A, Didan K, Miura T, Rodriguez EP, Gao X, Ferreira LG (2002) Overview of the radiometric and biophysical performance of the MODIS vegetation indices. Remote Sens Environ 83:195-213
Kenderes K, Aszalós R, Ruff J, Barton Z, Standovár T (2007) Effects of topography and tree stand characteristics on susceptibility of forests to natural disturbances (ice and wind) in the Börzsöny Mountains (Hungary). Community Ecol 8:209-220

La Puma IP, Philippi TE, Oberbauer SF (2007) Relating NDVI to ecosystem $\mathrm{CO}_{2}$ exchange patterns in response to season length and soil warming manipulations in arctic Alaska. Remote Sens Environ 109:225-236

Ma Z-Q, Wang H-M, Wang S-Q, Li Q-K, Wang Y-D, Wang H-Q (2010) Impact of a severe ice storm on subtropical plantations at Qianyanzhou, Jiangxi, China. Chin J Plant Ecol $34: 204-212$

Mi N, YU G-R, Wang P-X, Wen X-F, Sun X-M (2006) A preliminary study for spatial representiveness of flux observation at ChinaFLUX sites. Science in China Ser. D 49(SII):24-35

Moffat AM, Papale D, Reichstein M et al (2007) Comprehensive comparison of gap-filling techniques for eddy covariance net carbon fluxes. Agric For Meteorol 147:209-232

NASA (2009) Primary Data Search, WIST NASA

Olthof I, King DJ, Lautenschlager RA (2004) Mapping deciduous forest ice storm damage using Landsat and environmental data. Remote Sens Environ 89:484-496

Papale D, Valentini R (2003) A new assessment of European forests carbon exchanges by eddy fluxes and artificial neural network spatialization. Glob Chang Biol 9:525-535

Papale D, Reichstein M, Canfora E, Aubinet M, Bernhofer C, Longdoz B, Kutsch W, Rambal S, Valentini R, Vesala T, Yakir D (2006) Towards a standardized processing of Net Ecosystem Exchange measured with eddy covariance technique: algorithms and uncertainty estimation. Biogeosciences 3:571-583

Peguero-Pina JJ, Morales F, Gil-Pelegrín E (2008) Frost damage in Pinus sylvestris L. stems assessed by chlorophyll fluorescence in cortical bark chlorenchyma. Ann For Sci 65:813

Reichstein M, Falge E, Baldocchi D et al (2005) On the separation of net ecosystem exchange into assimilation and ecosystem respiration: review and improved algorithm. Glob Chang Biol 11:1424-1439

Reichstein M, Tenhunen JD, Roupsard O, Ourcival J-M, Rambal S, Dore S, Valentini R (2002) Ecosystem respiration in two Mediterranean evergreen Holm Oak forests: drought effects and decomposition dynamics. Funct Ecol 16:27-39

Richardson AD, Hollinger DY (2007) A method to estimate the additional uncertainty in gap-filled NEE resulting from long gaps in the $\mathrm{CO}_{2}$ flux record. Agric For Meteorol 147:199208

Richardson AD, Hollinger DY, Burba GG,Davis KJ, Flanagan LB, Katul GG,Munger JW, Ricciuto DM, Stoy PC,Suyker AE, Verma SB, Wofsy SC (2006) A multi-site analysis of random error in tower-based measurements of carbon and energy fluxes. Agric For Meteorol 136:1-18

Savitzky A, Golay MJE (1964) Smoothing and Differentiation of Data by Simplified Least Squares Procedures. Anal Chem 36:1627-1639

Sun X-M, Zhu Z-L, Wen X-F, Yuan G-F, Yu G-R (2006) The impact of averaging period on eddy fluxes observed at ChinaFLUX sites. Agric For Meteorol 137:188-193

Tremblay M, Messier C, Marceau DJ (2005) Analysis of deciduous tree species dynamics after a severe ice storm using SORTIE model simulations. Ecol Model 187:297-313

Webb EK, Pearman GI, Leuning R (1980) Correction of flux measurements for density effects due to heat and water vapor transfer. Q J R Meteorol Soc 106:85-100

Wen X-F, Yu G-R, Sun X-M, Li Q-K,Liu Y-F, Zhang L-M, Ren C-Y,Fu Y-L, Li Z-Q(2006) Soil moisture effect on the temperature dependence of ecosystem respiration in a subtropical 
Pinus plantation of southeastern China. Agric For Meteorol 137:166-175

Wen XF, Wang HM, Yu GR, Sun X-M (2009) Ecosystem carbon exchange of a subtropical evergreen coniferous plantation subjected to seasonal drought, 2003-2007. Biogeosci Discuss 6:8691-8723

Wen XF, Wang HM, Wang JL, Yu GR, Sun X-M (2010) Ecosystem carbon exchanges of a subtropical evergreen coniferous planta- tion subjected to seasonal drought, 2003-2007. Biogeosciences 7:357-369

Wilczak J, Oncley S, Stage S (2001) Sonic anemometer tilt correction algorithms. Boundary Layer Meteorol 99:127150

Yu G, Zhang L, Sun X et al (2008) Environmental controls over carbon exchange of three forest ecosystems in eastern China. Glob Chang Biol 14:2555-2571 